Laboratoire de Recherche en Gestion

$\&$ Economie
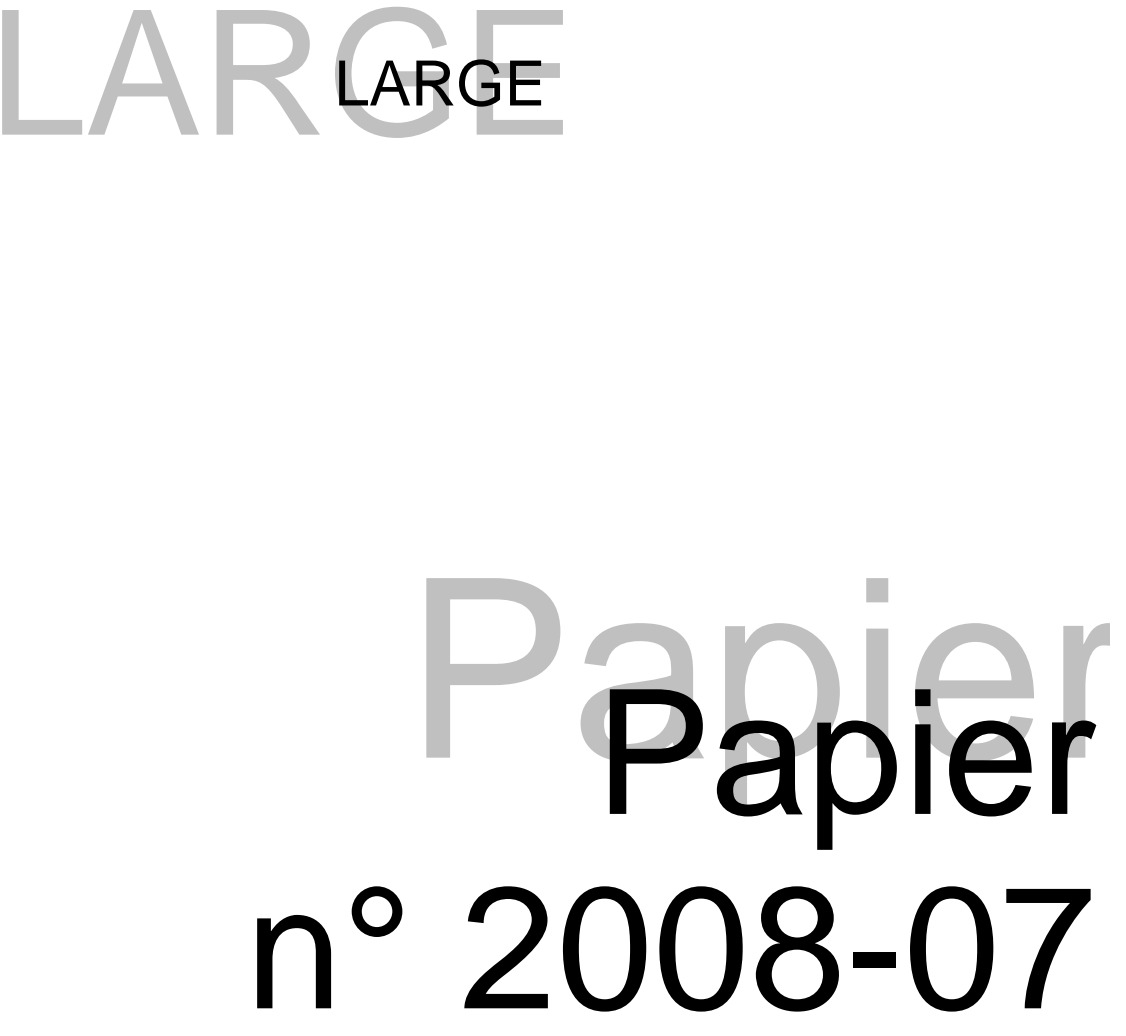

Convergence in Banking Efficiency Across European Countries

Laurent Weill

Février 2008

Faculté des

sciences économiques

et de gestion

PEGE

61, avenue de la Forêt Noire 67085 STRASBOURG Cedex

Tél. : (33) 0390242152

Fax : (33) 0390242064

www-ulp.u-strasbg.fr/large 


\title{
Convergence in Banking Efficiency across European Countries
}

\author{
Laurent Weill ${ }^{1}$ \\ LARGE, Université Robert Schuman, Institut d'Etudes Politiques, \\ 47 avenue de la Forêt-Noire, 67082 Strasbourg Cedex, France.
}

\begin{abstract}
:
Since the preparation of the Single Market program in the 80s, financial integration in Europe has been expected to provide gains in growth by favoring competition and efficiency on financial markets. Our paper aims to check whether financial integration has taken place on the banking markets, by investigating the convergence in banking efficiency for European Union countries. We measure cost efficiency of banks from 10 EU countries between 1994 and 2005 with the stochastic frontier approach. Our work then constitutes the first one to apply tests of $\beta$ and $\sigma$ convergence specified for panel data on banking efficiency measures.

We provide evidence of cross-country differences in cost efficiency and of an improvement in cost efficiency for all EU countries. Tests of convergence support the view of a process in convergence in cost efficiency between EU countries. Robustness checks with alternative specifications confirm these findings. These results support the view that financial integration has taken place on the EU banking markets in the recent years.
\end{abstract}

Keywords: banking, convergence, efficiency, European integration, stochastic frontier approach. JEL Classification: G21, D21, F36

\footnotetext{
${ }^{1}$ Tel : 33-3-88-41-77-54 ; fax : 33-3-88-41-77-78 ; e-mail : laurent.weill@urs.u-strasbg.fr I would like to thank Christophe Godlewski for his help. I am grateful to David Humphrey, Jakob Bikker, Evan Kraft, José Manuel Campa, Leonardo Becchetti, Mohammed Chaffai, and the seminar participants of the North American Workshop on Productivity and Efficiency in New York (June 2006), of the Congress of the European Association for Research in Industrial Economics in Amsterdam (August 2006), of the $25^{\text {th }}$ SUERF Colloquium on Competition and Profitability in European Financial Services in Madrid (October 2004) for their remarks on earlier versions of this paper.
} 


\title{
Convergence in Banking Efficiency across European Countries
}

\begin{abstract}
:
Since the preparation of the Single Market program in the 80s, financial integration in Europe has been expected to provide gains in growth by favoring competition and efficiency on financial markets. Our paper aims to check whether financial integration has taken place on the banking markets, by investigating the convergence in banking efficiency for European Union countries. We measure cost efficiency of banks from 10 EU countries between 1994 and 2005 with the stochastic frontier approach. Our work then constitutes the first one to apply tests of $\beta$ and $\sigma$ convergence specified for panel data on banking efficiency measures.

We provide evidence of cross-country differences in cost efficiency and of an improvement in cost efficiency for all EU countries. Tests of convergence support the view of a process in convergence in cost efficiency between EU countries. Robustness checks with alternative specifications confirm these findings. These results support the view that financial integration has taken place on the EU banking markets in the recent years.
\end{abstract}

Keywords: banking, convergence, efficiency, European integration, stochastic frontier approach. JEL Classification: G21, D21, F36 


\section{Introduction}

Since the preparation of the Single Market program in the 80s, financial integration in Europe has been expected to provide gains in growth by favoring competition and efficiency on financial markets (European Economy, 1988; European Commission, 2002; Guiso et al., 2004). These gains should result from price reductions in financial services leading to direct gains for consumers and indirect gains through the reduction of loan rates favoring investment. It is therefore of utmost interest to investigate whether financial integration has taken place in the EU.

The objective of this paper is to provide evidence on this topic by focusing on banking integration. The main aim of banking integration is the convergence towards the one price law, according to which all banks should charge the same price for similar products. To reach this objective, convergence in cost efficiency of banks is required as large differences in banking costs prevent banking prices from converging. Therefore, the investigation of convergence in cost efficiency of banks informs on the degree of banking integration in the EU.

Our objective in this paper is thus to assess the convergence of cost efficiency for the EU banking sectors in the recent years. We estimate cost efficiency of EU banks with the stochastic frontier approach. We then analyze the evolution and convergence in cost efficiency. One great innovation of our paper is the application of tests of convergence specified for panel data on banking efficiency measures. We make use of two major concepts of convergence, $\beta$-convergence and $\sigma$-convergence. $\beta$-convergence implies that countries with a lower level of banking efficiency have faster growth rates than countries with a higher level of banking efficiency. $\sigma$-convergence is observed if each country's level of banking efficiency is converging to the average level of the group of countries.

To our knowledge, Fung (2006) is the only paper performing a test of convergence on banking efficiency measures. However, the objectives were far different from ours with an investigation on the convergence in pure technical efficiency and scale efficiency for the US bank holding companies. Furthermore, on the methodological side, this work has not applied the specifications of the convergence tests for panel data.

Our paper then extends the established literature on banking efficiency in EU countries (e.g. Lozano-Vivas, Pastor and Hasan, 2001; Lozano-Vivas, Pastor and Pastor, 2002). In this latter strand of literature, several papers have indeed investigated banking efficiency in EU 
countries to notably analyze the cross-country differences. Lozano-Vivas, Pastor and Hasan (2001) notably estimated a cross-country production frontier on a sample of banks from 10 EU countries with the non-parametric DEA approach. Vander Vennet (2002) investigated cost and profit efficiency on a sample of banks from 17 European countries. The main conclusion of these papers is the existence of substantial discrepancies in banking efficiency across EU countries. However several studies have underlined the fact that, after controlling for environment, cross-country differences in banking efficiency are substantially reduced (Lozano-Vivas, Pastor and Pastor, 2002; Carbo Valverde, Humphrey and Lopez del Paso, 2007).

Furthermore, a few studies have investigated the evolution of banking efficiency in the EU countries since the nineties so as to provide evidence on the effects of European integration on banking efficiency. Most of these works conclude in favor of an increase in efficiency for EU banks (Altunbas et al., 2001; Carbo Valverde, Gardener and Wiliams, 2002; Casu and Molyneux, 2003), even if some papers provide more ambiguous results (Schure, Wagenvoort and O’Brien, 2004; Maudos and Fernandez de Guevara, 2007).

The structure of the paper is as follows. Section 2 develops the evolution of the EU banking sectors over the last decade. Section 3 outlines the methodology used for the cost efficiency measures and the convergence tests. Section 4 describes the data and variables. Section 5 develops the empirical results. Finally, we provide some concluding remarks in section 6 .

\section{Background}

As we focus on the evolution of banking efficiency in the EU countries during the nineties, the presentation of the legal changes and the evolution of banking structure in these countries is required. We briefly go thru the legal progress made towards a single banking market in the EU. The Treaty of Rome in 1957 already set out the principles for a single banking market, by asserting the will to achieve a single common market for goods and services resorting to two instruments: the recognition of the right of establishment and the coordination of legislation if that proved to be necessary. Nevertheless, there was no coordination of banking supervision, while the restrictions on capital flows limited international competition in banking. 
A first step was taken towards progress with the adoption of the First Banking Directive in 1977, affirming the principle of home country control. But this directive could be regarded more like a program as no specific regulation has ever been implemented in favor of this principle. A watershed in this field was the adoption of the Single European Act in 1986, stating the completion of the single market through the free circulation of people, goods and services, and capital in 1992. This was the very starting point of banking integration in the EU with the adoption of the Directive on Liberalization on Capital Flows in 1988, and more particularly the Second Banking Directive in 1989. This latter text established the single banking license: any bank authorized to provide banking services in a EU state was from then on allowed to provide banking services in another EU state. In practice, by reducing legal barriers to entry on foreign banking markets, this directive was expected to favor the cross-border expansion of banking services through either the creation of branches or the supply of cross-border financial services. The creation of subsidiaries was not favored as they were still submitted to the control of the host country authority.

The creation of the single currency in 1999 was another step taken towards an integrated European banking market, as it removed the exchange risk for banks in the cross-border acquisitions and in the supply of cross-border services. However the way to the integration of the banking markets was still punctuated with legal obstacles. Therefore, the Financial Services Action Plan (FSAP) was launched in 1999 to be implemented in 2005. This plan had three aims: the creation of a single EU wholesale market for financial services and products, the creation of an open and secure financial retail market, and the implementation of state of the art prudential rules and supervision. Therefore it aimed to implement integrated wholesale banking markets, and to develop the prudential regulation and the openness of the retail banking markets. It was then a set of 42 measured intended to reach these aims.

Consequently, the analysis of the legal efforts to promote banking integration in the EU shows major changes. Indeed, great efforts have been performed in particular through the Second Banking Directive and the Liberalization of Capital Flows, reducing the legal barriers to entry. However, some legal obstacles remain, notably the consumer protection rules and the tax rules.

We turn now to the evolution of the structure of the EU banking markets, to analyze notably the outcome of these legal changes. According to the figures provided by Cabral, Dierick and Vesala (2002) from Thomson Financial database, there happened a wave of mergers and acquisitions in the EU financial sectors during the 90s. Nevertheless these 
movements were mostly domestic until 1999. Indeed approximately $80 \%$ of the value of mergers and acquisitions was represented by domestic transactions. Consequently, these movements may not have fostered competition since they winded up in a decrease of the number of banks on the national banking markets. Furthermore, defensive motives might have grounded the decisions of banks, such as a higher size to prevent a takeover, or the increase of market power. Therefore, mergers and acquisitions mostly spark off higher concentration at the national level.

This observation is confirmed by the evolution of the number of banks and of bank branches between 1994 and 2005 (ECB, 2007). We observe a reduction of the number of banks during this period in all ten countries investigated in our analysis. We could then expect a negative influence from this movement of domestic concentration on the number of bank branches, as mergers and acquisitions may spark off overbranching for some new entities. However it did not trigger off a generalized reduction of the number of branches. We even observe an increase of the number of branches in some countries during the period.

Why such an expansion? A possible explanation is based on the implementation of strategic barriers to entry. Indeed, Yafeh and Yosha (2001) showed that banks can implement barriers to entry by increasing their customership, so that the switching costs for the customers (resulting among others from the best information owned by the bank on its borrower) prevent the potential competitors from enter the market. Therefore, the expectations of new competitors may have incited European banks to increase the number of branches so as to have a larger customership. This behavior may have reached its peak in countries with poor levels of banking efficiency, as banks originating from these countries are the most threatened by foreign competition.

The consequences of these changes on banking competition can then be measured. Several works have then shown the absence of increased competition during the nineties and the first half of the current decade. Fernandez de Guevara, Maudos and Perez (2005) support the absence of increased competition on EU banking markets during the 90s. They compute a Lerner index of market power for the banking sectors of the five biggest EU countries between 1992 and 1999. Their results then do not show an increase in competition within the EU. Fernandez de Guevara, Maudos and Perez (2007) perform a similar investigation for the 15 EU banking sectors between 1993 and 2000. They conclude to an improvement of the market power for 10 (including France, Italy, the UK, and Spain) of the 15 EU banking sectors. 
In a related study, Goddard, Molyneux and Wilson (2004) investigate profitability of EU banks in six EU countries between 1992 and 1998 and observe a significant persistence of abnormal profit during that period. The absence of increased competition in the EU banking sectors during the 90s may seem surprising, as there is consensual evidence regarding the reduction of margins in these sectors. Maudos and Fernandez de Guevara (2004) however explain how the fall of margins in EU banking was compatible with a relaxation of competitive conditions, and notably an increase of market power, during that period. They indeed show that EU banks benefited during the 90s from a reduction of interest rate risk, credit risk, and also of operating costs which allow them to reduce their margins without decreasing their market power.

To sum it up, banking integration in the EU was favored through several legal changes. But some obstacles remain as cross-border mergers and acquisitions remained scarce in the banking industry, and as there was no increase of banking competition. Furthermore, Dermine (2003) stressed that the effects on banking integration from the Second Banking Directive may have been an illusion. Indeed this directive made the cross-border expansion through branches easier, but in practice this expansion took place via subsidiaries rather than via branches. Therefore, some barriers still prevent the implementation of the Single Banking Market. These obstacles notably include political barriers to entry such as the will of some national authorities to prevent the takeover of large national banks by foreign interests, as observed by Boot (1999). They also include sunk costs making ex nihilo creation of a network of branches hard, and switching costs resulting in barriers to entry for new competitors.

Banking integration seems thus far from being completed. However, even if obstacles remain and no improvement of banking competition was observed, it appears relevant to analyze the convergence of cost efficiency to assess the effective effects of banking integration on the behavior of banks. Indeed, even if there was no increase of competition, banking behavior may for instance have been affected by the implementation of the Euro and the expected cross-border mergers. Furthermore, competition policy from European authorities may have shrunk the possibilities of collusion for banks. 


\section{Methodology}

\subsection{Efficiency measures}

Our aim is to measure cost efficiency of European banks, so as to investigate the evolution and the convergence in efficiency between 1994 and 2005. Cost efficiency measures how close the cost for a bank is to what it should be like for a best-practice bank for producing the same bundle of outputs. Several techniques have been proposed in the literature to measure efficiency with frontier approaches. They mainly differ in the distributional assumptions used to disentangle inefficiency differences from random errors. We apply the stochastic frontier approach, which disentangles inefficiency from random error by assuming a normal distribution for the random error and a one-sided distribution for the inefficiency term. This approach is commonly used in works measuring banking efficiency (Hasan and Marton, 2003; Bonin, Hasan and Wachtel, 2005).

The basic model assumes that total cost deviates from the optimal cost by a random disturbance, $v$, and an inefficiency term, $u$. Thus the cost function is $T C=f(Y, P)+\varepsilon$ where TC represents total cost, $\mathrm{Y}$ is the vector of outputs, $\mathrm{P}$ the vector of input prices and $\varepsilon$ the error term which is the sum of $\mathrm{u}$ and $\mathrm{v}$. $\mathrm{u}$ is a one-sided component representing cost inefficiencies, meaning the degree of weakness of managerial performance. $v$ is a two-sided component representing random disturbances, reflecting bad (good) luck or measurement errors. $\mathrm{u}$ and $\mathrm{v}$ are independently distributed. $\mathrm{v}$ is assumed to have a normal distribution. We assume a gamma distribution following Greene (1990). Following Jondrow et al. (1982), bank-specific estimates of inefficiency terms can be calculated by using the distribution of the inefficiency term conditional to the estimate of the composite error term. Greene (1990) has then provided the estimate of the cost inefficiency term with a gamma distribution. ${ }^{2}$

We estimate a system of equations composed of a Fourier-flexible cost function and its associated input cost share equations, derived using Shepard's lemma. We choose the Fourier-flexible form, since it was proved to dominate the translog form (McAllister and McManus, 1993). We adopt here the specification with only Fourier terms for the output quantities following Berger, Leusner and Mingo (1997) and Altunbas et al. (2001).

Estimation of this system adds degrees of freedom and results in more efficient estimates than the mere single-equation cost function. Since the share equations sum to unity,

\footnotetext{
${ }^{2}$ See Kumbhakar and Lovell (2000) for further details on Stochastic Frontier Analysis.
} 
we solve the problem of singularity of the disturbance covariance matrix of the share equations by omitting one input cost share equation from the estimated system of equations. Standard symmetry constraints are imposed. Homogeneity conditions are imposed by normalizing total costs, price of labor, and price of physical capital, by the price of borrowed funds. Thus, the complete model is the following:

$$
\begin{aligned}
& \ln \left(\frac{\mathrm{TC}}{\mathrm{w}_{3}}\right)=\beta_{0}+\sum_{\mathrm{m}} \alpha_{\mathrm{m}} \ln \mathrm{y}_{\mathrm{m}}+\sum_{\mathrm{n}} \beta_{\mathrm{n}} \ln \left(\frac{\mathrm{w}_{\mathrm{n}}}{\mathrm{w}_{3}}\right)+\frac{1}{2} \sum_{\mathrm{m}} \sum_{\mathrm{j}} \alpha_{\mathrm{mj}} \ln \mathrm{y}_{\mathrm{m}} \ln \mathrm{y}_{\mathrm{j}} \\
& \quad+\frac{1}{2} \sum_{\mathrm{n}} \sum_{\mathrm{k}} \beta_{\mathrm{nk}} \ln \left(\frac{\mathrm{w}_{\mathrm{n}}}{\mathrm{w}_{3}}\right) \ln \left(\frac{\mathrm{w}_{\mathrm{k}}}{\mathrm{w}_{3}}\right)+\sum_{\mathrm{n}} \sum_{\mathrm{m}} \gamma_{\mathrm{nm}} \ln \left(\frac{\mathrm{w}_{\mathrm{n}}}{\mathrm{w}_{3}}\right) \ln \mathrm{y}_{\mathrm{m}} \\
& \quad+\sum_{\mathrm{k}}\left[\delta_{\mathrm{k}} \cos \mathrm{Z}_{\mathrm{k}}+\theta_{\mathrm{k}} \sin \mathrm{Z}_{\mathrm{k}}\right]+\sum_{\mathrm{k}} \sum_{\mathrm{l}=\mathrm{k}}\left[\delta_{\mathrm{kl}} \cos \left(\mathrm{Z}_{\mathrm{k}}+\mathrm{Z}_{\mathrm{l}}\right)+\theta_{\mathrm{kl}} \sin \left(\mathrm{Z}_{\mathrm{k}}+\mathrm{Z}_{1}\right)\right] \\
& \quad+\sum_{\mathrm{k}} \sum_{\mathrm{l}=\mathrm{k}} \sum_{\mathrm{m}=1}\left[\delta_{\mathrm{klm}} \cos \left(\mathrm{Z}_{\mathrm{k}}+\mathrm{Z}_{\mathrm{l}}+\mathrm{Z}_{\mathrm{m}}\right)+\theta_{\mathrm{klm}} \sin \left(\mathrm{Z}_{\mathrm{k}}+\mathrm{Z}_{\mathrm{l}}+\mathrm{Z}_{\mathrm{m}}\right)\right]+\varepsilon \\
& S_{n}=\partial \ln \left(\frac{T C}{w_{3}}\right) / \partial \ln w_{n}=\beta_{n}+\sum_{k} \beta_{n k} \ln \left(\frac{w_{k}}{w_{3}}\right)+\sum_{m} \gamma_{n m} \ln y_{m}+\eta_{n}
\end{aligned}
$$

with $Z_{i}=0.2 \pi+(1.6 \pi)^{*} \frac{\ln Y_{i}-\ln Y_{i, \min }}{\ln Y_{i, \max }-\ln Y_{i, \min }}$

where TC total costs, $y_{m} m^{\text {th }}$ bank output $(m=1,2), w_{n} n^{\text {th }}$ input price $(n=1,2), w_{3}$ price of borrowed funds, $S_{n}$ input cost share ${ }^{3}(n=1,2)$, $\eta_{n}$ error term $\left(\eta_{n}\right.$ independent from $\varepsilon$ ). Indices for each bank have been dropped in the presentation for simplicity. The system of equations is estimated using Iterative Seemingly Unrelated Regression (ITSUR) estimation technique. We estimate the SFA model for each year, allowing changes over time in the technology.

\subsection{Tests of convergence}

We now present the tests of convergence performed to investigate convergence in efficiency. The issue of convergence has been widely studied in the growth literature during the last decade. Barro and Sala-i-Martin (1991) propose two concepts of convergence, $\beta$ (beta) and $\sigma$-(sigma) convergence which are developed in a cross-section context.

The $\beta$-convergence test aims to regress the growth rate on the initial level for any variable. There is then convergence of the $\beta$-type whether the growth rate is negatively correlated with the initial level. That is, $\beta$-convergence implies that countries with low initial level have faster growth rates than countries with high initial level. Some limits of this test 
have been underlined by Quah (1996). First, the interpretation of the result in terms of convergence is not straightforward. That is to say, if countries with low initial level grow faster than those with high initial level, this can lead to a situation where the first ones overpass the latter ones, meaning the absence of convergence. Second, the $\beta$-convergence test provides no information on the evolution of the dispersion of the cross-section.

The $\sigma$-convergence test does not suffer from these limits. It aims to investigate the evolution of the dispersion of a cross-section. There is then convergence if the dispersion diminishes over time. Thus, $\sigma$-convergence captures how quickly each country's level is converging to the average level of the group of countries. These two measures of convergence are complementary, but not excludable: $\beta$-convergence is a necessary but not a sufficient condition for $\sigma$-convergence to take place.

Both these tests are the most generally applied tests of convergence in the literature. We apply them to investigate the convergence in banking efficiency for the whole sample of countries between 1994 and 2005. To take account of both the intertemporal pattern of convergence and the cross-sectional variety of the EU countries, we use the specifications of convergence tests for panel data.

The $\beta$-convergence test is performed through the estimation of the following equation, following the specification for panel data from Canova and Marcet (1995):

$$
\ln E F F_{i, t}-\ln E F F_{i, t-1}=\alpha+\beta \ln E F F_{i, t-1}+\sum_{i=1}^{9} D_{i}+\varepsilon_{i, t}
$$

Where $E F F_{i, t}$ the mean cost efficiency score of banks of country i in year t, $E F F_{i, t-1}$ the efficiency score of country i in year t-1, $D_{i}$ country dummies, $\varepsilon_{i}$ the error term, and $\alpha$ and $\beta$ the parameters to be estimated. Country dummies incorporate fixed effects for countries in the equation to disentangle the country effects. There is then $\beta$-convergence if the coefficient $\beta$ of the initial level is negative. The values diverge from each other as quick as from their initial level (meaning that the gap between $E F F_{i, t}$ and $E F F_{i, t-1}$ is as larger) and consequently countries converge all the quicker as $\beta$ is high.

$\sigma$-convergence is investigated through the estimation of the following equation, following the specification for panel data used notably by Parikh and Shibata (2004):

$$
\Delta W_{i, t}=\alpha+\beta W_{i, t-1}+\sum_{i=1}^{9} D_{i}+\varepsilon_{i, t}
$$

\footnotetext{
${ }^{3} S_{n}$ is equal to the expenses for the input $n$ divided by total costs.
} 
Where $\ln E F F_{i, t}$ the logarithm of the mean cost efficiency score of banks of country i in year t, $M E F F_{t}$ the mean of $\ln E F F_{i, t}$ for each period, $W_{i, t}=\ln E F F_{i, t}-M E F F_{t}, \Delta W_{i, t}=W_{i, t}$ $W_{i, t-1}, D_{i}$ country dummies, $\varepsilon_{i}$ the error term, and $\alpha$ and $\beta$ the parameters to be estimated. Country dummies incorporate fixed effects for countries in the equation to disentangle the country effects. There is then $\sigma$-convergence if the coefficient $\beta$ of the initial level is negative.

\section{Data and variables}

Data are taken from the "Bankscope" database of BVD-IBCA. We use unconsolidated accounting data for a sample of banks from $10 \mathrm{EU}$ member countries (Austria, Belgium, Denmark, France, Germany, Italy, Luxembourg, Portugal, Spain, the United Kingdom). The lack of sufficient data in our database concerning the five other member states brought us not to include all EU countries. This sample of EU countries is however satisfactory for an investigation of the evolution in banking efficiency in EU countries, as it includes the major EU countries.

Our sample includes commercial, cooperative and savings banks. The period of observation stretches from 1994 up to 2005. We use an unbalanced panel, as the choice of a balanced sample would spark off overestimating cost efficiency. Indeed, we would not take into account the banks gone into bankrupt and those being absorbed during this period. We adopt the Tukey box-plot, based on the use of interquartile range to clean data: banks with observations out of the range defined by the first and third quartiles that are greater or less than one and half the interquartile range were dropped for each input price for each year. These criteria produce a sample of 14,447 observations.

For the definition of inputs and outputs, we adopt the intermediation approach, following Altunbas et al. (2001) and Bonin, Hasan and Wachtel (2005) among others. It assumes that the bank collects deposits to transform them, using labor and capital, into loans as opposed to the production approach, which views the bank as using labor and capital to produce deposits and loans. Two outputs are included: loans, and investment assets ${ }^{4}$. The inputs, whose prices are used to estimate the cost frontier, include labor, physical capital and

\footnotetext{
${ }^{4}$ This item includes the « other earning assets » in the IBCA terminology, which are all the earning assets other than loans.
} 
borrowed funds. As data on the number of employees are not available, the price of labor is measured by the ratio of personnel expenses to total assets, following Altunbas et al. (2001) and Maudos et al. (2002) among others ${ }^{5}$. The price of physical capital is defined as the ratio of other non-interest expenses to fixed assets. The price of borrowed funds is measured by the ratio of paid interests to all funding. Total costs are the sum of personnel expenses, other non-interest expenses and paid interest. Summary statistics by country are reported in tables A.1 and A.2 in Annex.

\section{Results}

This section is devoted to the presentation of our results. We first display the main findings. We then provide some robustness checks. We attempt afterwards to provide some explanations.

\subsection{Findings}

We investigate the evolution of cost efficiency for EU banks between 1994 and 2005. The mean efficiency scores for each country and each year are displayed in table $2 .{ }^{6}$ Several conclusions come to the front.

First, we observe large discrepancies in banking efficiency between EU countries. In 1994, the efficiency means range from $61.03 \%$ in Portugal to $78.90 \%$ in France, while they range from $80.32 \%$ in Spain up to $90.88 \%$ in Luxembourg in 2005. This consequently means a reduction of the gap between the least and the most efficient banking sector between 1994 and 2005. This finding suggests that, even if cross-country differences in banking efficiency remain substantial in 2005, they have decreased over the period.

Second, we observe an increase in banking efficiency for all EU countries of our sample. There remain however quite large differences in this improvement with increases ranging from 6.58 points in France up to 27.31 points in Portugal. Table 2 also records the

\footnotetext{
${ }^{5}$ As observed by Maudos et al. (2002), this variable can be interpreted as labor cost per worker (personnel expenses / number of employees) adjusted for differences in labor productivity (number of employees / total assets), since it is the product of these ratios.
} 
significance levels for t-tests for comparisons between 1994 and 2005 for the mean efficiency scores. We point out that the mean efficiency scores are greater in 2005 than in 1994 in all countries, with the exception of the United Kingdom.

Third, we observe some features of a catching-up process in banking efficiency between countries as the two countries with the least efficient banking sectors in 1994 (in ascending order Portugal, and Spain) are among the three countries with the highest improvement in banking efficiency between 1994 and 2005.

Consequently, our main conclusion is the improvement of efficiency between 1994 and 2005 in all EU countries. This finding is ground for optimism, as it tends to support the view that European integration had a positive impact on cost efficiency of banks in the nineties. When comparing our findings with the scarce former studies on this topic, we point out that most also found an increase in efficiency for EU banks. Altunbas et al. (2001) conclude to a increase in cost efficiency of EU banks between 1989 and 1997. Carbo, Gardener and Williams (2002) observe a slight improvement of cost efficiency for EU savings banks between 1989 and 1996. Casu and Molyneux (2003) point out an improvement in technical efficiency between 1993 and 1997 for five European countries. Schure, Wagenvoort and O’Brien (2004), obtain more ambiguous findings on the EU countries between 1993 and 1997. However, while they do not conclude in favor of an improvement in banking efficiency, they also support the view of the reduction of the cost base of European banks during this period. A notable exception is the work from Maudos and Fernandez de Guevara (2007) providing estimates of cost efficiency for banks from the 15 EU countries between 1993 and 2002. As a whole, they point out the stability of banking efficiency for the full sample. However they also observe cross-country differences in the evolution of efficiency for the EU countries.

Furthermore, the country-by-country analysis seems to support the hypothesis of convergence in banking efficiency in the EU between countries, as countries with the least efficient banking sectors in 1994 are among the countries with the highest improvement in efficiency during the period of the study. Nonetheless, more investigation is needed to analyze the convergence of banking efficiency between EU countries.

Following the observed evolution of banking efficiency, tests of convergence are of utmost interest so as to analyze the reality of a movement of convergence in banking

\footnotetext{
${ }^{6}$ The ITSUR estimation of the cost function system for each year is available upon simple request. Based on the individual t-statistics and the value of the adjusted $\mathrm{R}^{2}$ statistic on the OLS equations, the fit of the equations is satisfactory for all yearly estimations.
} 
efficiency across EU countries. We consequently test $\beta$ and $\sigma$ convergence in banking efficiency. Specifications of convergence tests for panel data are then adopted, which were presented in the methodology. Both tests are performed for the full sample of countries between 1994 and 2005. The results of the $\beta$-tests and the $\sigma$-tests are displayed in table 3 . We provide evidence about $\beta$-convergence and $\sigma$-convergence in banking efficiency between European countries. Indeed the coefficient $\beta$, which is respectively the coefficient of $\log E F F_{i, t}$ and $W_{i, t-1}$ for $\beta$-tests and $\sigma$-tests, is negative and significant at the $1 \%$ level in all tests.

Thus, a major finding is the convergence in banking efficiency across EU countries. We support $\beta$-convergence, i.e. the most efficient banking sectors in 1994 have known a lower improvement of efficiency than the least efficient banking sectors in 1994, but also $\sigma$ convergence, meaning that the dispersion of the mean efficiency scores between EU countries was reduced during the period of study.

\subsection{Robustness checks}

Our robustness checks include two tests. The first one investigates the issue of the choice of the frontier efficiency model. The second one analyzes the impact of the specification of inputs and outputs on the findings.

First, we check whether our findings are robust to the choice of the frontier efficiency technique. Indeed, as mentioned above, there are several techniques to estimate the efficiency scores, differing notably in the adopted tools, econometrics or linear programming, and in the assumptions used to disentangle the residual from the frontier between the inefficiency term and a white noise. A couple of studies have tested the robustness of efficiency scores provided by different techniques (e.g. Bauer et al., 1998, on US banks, Weill, 2004, on European banks). Their main conclusion is that the influence of the choice of the approach on the efficiency results is by no means insignificant. It is therefore fundamental to use another frontier technique to validate its conclusions.

We use the time-varying WITHIN model proposed by Cornwell, Schmidt and Sickles (1990), which was scarcely applied in studies on banking efficiency (e.g. Esho, 2001). As this technique is based on the use of panel data, we consider it as particularly relevant for our analysis. By using panel data, the WITHIN model does not require distributional 
assumptions on the inefficiency term and the random disturbance. The term $\varphi_{i t}$ is modelled as follows:

$$
\varphi_{i t}=\theta_{1 i}+\theta_{2 i} t+\theta_{3 i} t^{2}
$$

where $\varphi_{i t}=\varphi-u_{i t}$, i indexes bank, t represents time, and the $\theta$ s are cross-section bankspecific parameters. It has to be stressed that an important difference between both frontier efficiency models is that the SFA model allows the coefficients of the production frontier to vary over time, which permits the technology changes during the period. This may notably trigger off some differences in the estimated distributional characteristics of the efficiency scores between both models.

The efficiency scores estimated with the WITHIN model are presented in table 4. We also observe large cross-country differences in banking efficiency between EU countries. For instance, the efficiency means range from $63.60 \%$ in Portugal to $77.28 \%$ in Italy in 2005. Furthermore, we point out again an improvement in banking efficiency between 1994 and 2005 in all countries, with larger variations over the period than with the SFA model. Finally, we observe again some evidence of a catching-up process in banking efficiency between countries. Indeed two of the three countries with the least efficient banking sectors in 1994 (Italy, and Luxembourg) are both countries with the highest improvement in banking efficiency between 1994 and 2005.

Tests of convergence for the efficiency scores with the WITHIN model are displayed in table 5 . The results of the $\beta$-tests and the $\sigma$-tests show again $\beta$-convergence and $\sigma$ convergence in banking efficiency between European countries.

Thus, the WITHIN model confirms the main findings obtained with the stochastic frontier model. Our results are then not dependent of the choice of the stochastic frontier approach for the estimation of efficiency scores.

Second, the choice of the specification of inputs and outputs may have influenced the findings. We have indeed adopted the intermediation approach and then consider deposits as an input. However, as several works have also adopted the production approach (e.g. Lozano-Vivas, Pastor and Hasan, 2001; Lozano-Vivas, Pastor and Pastor, 2002), it appear relevant to investigate whether this alternative specification leads to the same findings. We therefore proceed to new estimations with stochastic frontier approach by considering deposits as an output next to loans, while input prices are now price of labor and price of physical capital. 
The results of this specification are displayed in tables 6 and 7 respectively for the yearly efficiency scores and for the convergence tests. Here again we point out important cross-country differences in banking efficiency between EU countries, with a range of mean efficiency scores in 2005 from 70.11\% in Austria to 82.72\% in Denmark. The improvement in banking efficiency is again observed for all EU countries. Finally the convergence tests show once more $\beta$-convergence and $\sigma$-convergence in banking efficiency between European countries.

Consequently, we conclude that the robustness tests do not hamper our key findings regarding the improvement and the convergence in banking efficiency for EU countries during the recent years. Therefore, these tests strengthen our main conclusion regarding $\beta$ convergence and $\sigma$-convergence in banking efficiency across EU countries.

\subsection{Discussion}

Our empirical results finish up with two major findings regarding the evolution of cost efficiency in the EU banking sectors between 1994 and 2005. A noteworthy first finding is the improvement in efficiency in all EU banking sectors. The second finding is the convergence in efficiency across EU countries. We attempt now to discuss the alternative assumptions which may be suggested to explain these phenomena.

An intuitive explanation would be to link the changes in efficiency with the changes in competition. Indeed, the European authorities aimed to promote competition on markets of goods and services to improve efficiency thanks to the higher competitive pressures exerted on bank managers. Therefore, the observed improvement in efficiency could be in accordance with this expectation, as a consequence of the increase in competition.

However this explanation is only satisfactory if increased competition happened during the period of study. To investigate this explanation, we assess banking competition for each year with the Rosse-Panzar model (Rosse and Panzar, 1977), which has been widely applied in banking (e.g. De Bandt and Davis, 2000; Bikker and Haaf, 2002, for applications on European countries). It is a non-structural test, meaning that it takes into account the actual behavior of banks without using information on the structure of the banking market. It is based on the estimation of the H-statistic, which aggregates the elasticities of total revenues to the input prices. The $\mathrm{H}$-statistic determines the nature of market structure: it is equal to 0 in monopoly, between 0 and 1 in monopolistic competition, and 1 in perfect competition. 
The test is performed on our sample of European banks. Our aim is to have a measure of competition for each year and each country to assess the evolution of banking competition by country. We therefore run the Rosse-Panzar model for each country and each year to obtain estimates of input prices which are specific to each country and each year. The problem of this approach is that some national samples are very small, meaning that the estimations of the Rosse-Panzar model are very poor on a statistical basis. Therefore, we need to perform this test on our whole sample for each year. However, we need to have country-specific estimates of the coefficients of input prices to analyze banking competition for each country and not for the EU as a whole. In this aim, we include interactive terms for each input price, jointing the variable with a dummy variable for each country. Consequently, we estimate the following equation for the measurement of Rosse-Panzar statistic:

$$
\begin{aligned}
\ln R E V= & \alpha_{0}+\alpha_{1} \ln \text { ASSETS }+\alpha_{2} \ln \text { EQASS } \\
& +\sum_{k=1}^{7}\left(\beta_{k} *\left(\ln w_{1}\right) * \operatorname{COUNTRY} Y_{k}+\gamma_{k} *\left(\ln w_{2}\right) * \operatorname{COUNTRY} Y_{k}\right. \\
& \left.+\delta_{k} *\left(\ln w_{3}\right) * \operatorname{COUNTR} Y_{k}\right)
\end{aligned}
$$

where $R E V$ total revenues, $w_{1}, w_{2}$ and $w_{3}$ prices of labor, physical capital, and borrowed funds respectively which are defined below, ASSETS total assets, EQASS the ratio of equity

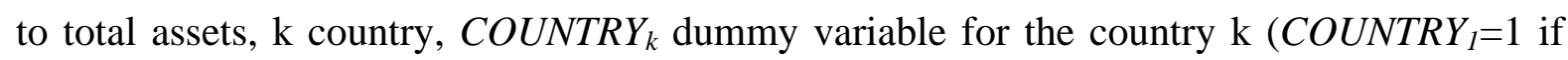
country is Austria, 0 else; $\operatorname{COUNTRY}_{2}=1$ if country is Belgium, 0 else,...). The variables ASSETS and EQASS take into account differences in size and risk respectively, akin to Bikker and Haaf (2002). Indices for each bank have been dropped in the presentation for simplicity.

The results of the Rosse-Panzar model are shown in table 8, providing several interesting findings. First, we observe values between 0 and 1 for all countries and all years, meaning a monopolistic competition structure in the EU banking markets. This result is in accordance with former studies on European banks (De Bandt and Davis, 2000; Bikker and Haaf, 2002). Second, the H-statistic decreased in all countries between 1994 and 2005. Consequently, we do not observe any improvement in competition during this period, but we rather tend to show an increase of the gap between market structure of EU banking markets and perfect competition. This reduction in competition then corroborates our observations on the increase in banking concentration at the national level, and on the strategic barriers to entry implemented in some countries through a higher number of bank branches. 
This finding is in line with those from Fernandez de Guevara, Maudos and Perez (2005), Maudos and Fernandez de Guevara (2007), and Goddard, Molyneux and Wilson (2004), who all support the absence of increased competition on EU banking markets during the period of our study. Consequently, as banking competition did not increase, greater competition can not explain higher efficiency in banking.

If we now turn to the possible role of convergence in competition on the convergence in efficiency, the explanation is however satisfactory. Indeed we have performed the tests of convergence on the measures of banking competition. The results of these estimations are displayed in table 9. We then point out $\beta$-convergence and $\sigma$-convergence in banking competition. Therefore, the convergence in banking competition may explain the observed convergence in banking efficiency.

Another explanation linked with the evolving structure of banking markets considers that domestic mergers and acquisitions may have favored cost efficiency of banks by increasing bank size. Indeed, evidence has pointed out the existence of scale economies in European banking (Altunbas and Molyneux, 1996, Cavallo and Rossi, 2001). As a consequence, a higher bank size might be associated with higher cost efficiency. This might explain the improvement in cost efficiency, even if we have to bear in mind three points which qualify this explanation. First of all, the existence of scale economies in European banking is not a sufficient condition to justify a positive link between bank size and cost efficiency, as it does not unquestionably entail that banks are able to exploit scale economies. Furthermore, we do not observe an increase of the average bank size between 1994 and 2005 in all countries, as there is a reduction of bank size in six countries. This trend is probably linked to the differences in national samples between both years, due to mergers, acquisitions and bankruptcies of banks, but also to limitations of Bankscope database which provides better information for recent years. Anyway, this reduction in bank size conveys the idea that the explanation based on an increased size linked with scale economies is not totally satisfactory to explain the improvement of cost efficiency in all EU countries. Finally, the economies of scale in connection with the mergers and acquisitions can contribute to explain the improvement in efficiency, but they do not provide a satisfactory explanation to the convergence in efficiency.

We therefore suggest two explanations which might contribute at various degrees the improvement and the convergence in banking efficiency of EU banks, keeping in mind that these explanations are just suggestions. Indeed, our findings do not allow supporting any of 
these views. But on the opposite, they provide evidence of the improvement in banking efficiency which is a first clue in favor of any of these views.

It may first be argued that the introduction of technical progress has contributed to the improvement in cost efficiency. Indeed, the efficiency scores are relative measures of performance. Therefore, the introduction of technical progress can not spark off a positive influence for all European banks, as it would then not affect the distribution of efficiency scores. However, it may be argued that the introduction of technical progress may have influenced the least efficient banks. Indeed technical progress can be suggested to favor a process of catching-up in cost performance among European banks. This view is supported by the reduction of technology costs for banks which makes easier the access to technology for all banks as time passes by. The introduction of technical progress may also have favored convergence in banking efficiency for similar reasons.

Second, EU banks were not much affected by banking integration in practice during the recent years, as there were only a few cross-border mergers and acquisitions while the cross-border establishment of branches and subsidiaries remains scarce. Nevertheless, even if competition did not increase with the arrival of foreign competitors, the perspective of the single banking market becoming more certain and closer may have incited banks to increase efficiency. Indeed a high level of efficiency allows bank managers to avoid sanctions either from banking markets by increasing the likelihood of survival on a market with the entry of new foreign competitors, or from equity markets by reducing the likelihood of a hostile takeover. Indeed the implementation of the single currency has removed the exchange risk for the cross-border establishment and even more for the cross-border supply of banking services.

Furthermore, the political barriers to entry endured by foreign competitors through acquisitions may appear less strong nowadays to banks, as the European authorities gained in power in relation to national governments. ${ }^{7}$ Therefore, even if competition did not increase, European banks were inclined to increase their efficiency so that they will be able to face new competition resulting from the entry of foreign banks. This explanation can also provide insights for the observed convergence in banking efficiency. Indeed these efforts to increase efficiency should have been greater in the countries with the least efficient banking industries.

\footnotetext{
${ }^{7}$ The intervention in 1999 of the European Commission in reaction to the veto of the Portuguese government in the attempt of the Spanish bank Banco Santander Central Hispano to buy a large stake of the Portuguese bank, Mundial Confianca, may be considered as an illustration of this change.
} 


\section{Conclusion}

This research has analyzed the convergence of cost efficiency in the EU banking sectors in the recent years. This issue is fundamental to assess the progress in banking integration, as convergence in cost efficiency of banks is a requirement for the convergence in banking prices. In this aim, we have applied the $\beta$-convergence and $\sigma$-convergence specified for panel data on cost efficiency scores for EU banks.

Our findings clearly support the view of a convergence in cost efficiency of banks across European countries. This result is observed for both concepts of convergence and is confirmed by our robustness tests, using alternative specifications. As a consequence, we provide evidence in favor of the process of banking integration in the European Union. Another finding is the observation of a generalized improvement in banking efficiency for all investigated EU countries, which supports the opinion that European integration had a positive impact on banking efficiency.

Therefore, our study provides evidence that banking integration in the EU has taken place in the recent years. One might expect that this process will accelerate in the forthcoming years with a greater number of cross-border mergers and acquisitions. A fundamental issue would then be to assess whether this process has contributed to welfare gains and more particularly to greater growth as initially expected by the planners of the Single Market Program. We let this issue for further research.

\section{REFERENCES}

Altunbas, Y., Gardener, E.P.M., Molyneux, P., Moore, B., 2001. Efficiency in European Banking. European Economic Review 45, 10, 1931--1955.

Altunbas, Y., Molyneux, P., 1996. Economies of Scale and Scope in European Banking. Applied Financial Economics 6, 4, 367--375.

Barro, R., Sala-I-Martin, X., 1991. Convergence across States and Regions. Brookings Papers on Economic Activity 1, 107--182.

Bauer, P., Berger, A., Ferrier, G., Humphrey, D., 1998. Consistency Conditions for Regulatory Analysis of Financial Institutions: A Comparison of Frontier Efficiency Methods. Journal of Economics and Business 50, 2, 85--114.

Berger, A., Leusner, J., Mingo, J., 1997. The Efficiency of Bank Branches. Journal of Monetary Economics 40, 1, 141--162.

Bikker, J., Haaf, K., 2002. Competition, Concentration and Their Relationship: An Empirical Analysis of the Banking Industry. Journal of Banking and Finance 26, 2191--2214. 
Bonin, J., Hasan, I., and Wachtel, P., 2005. Bank Performance, Efficiency and Ownership in Transition Countries. Journal of Banking and Finance 29, 31--53.

Boot, A., 1999. European Lessons on Consolidation in Banking. Journal of Banking and Finance 23, 609--613.

Cabral, I., Dierick, F., Vesala, J., 2002. Banking Integration in the Euro Area. Occasional Paper Series $n^{\circ} 6$, European Central Bank.

Canova, F., Marcet, A., 1995. The Poor Stay Poor: Non Convergence Across Countries and Regions. Presentation at the CEPR Workshop on Empirical Macroeconomics, Brussels.

Carbo Valverde, S., Gardener, E., Williams, J. 2002. Efficiency in Banking: Empirical Evidence from the Savings Banks Sector, Manchester School 70, 2, 204--228.

Carbo Valverde, S., Humphrey, D., Lopez del Paso, R., 2007. Do Cross-Country Differences in Bank Efficiency Support a Policy of 'National Champions'. Journal of Banking and Finance 31, 7, 2173-2188.

Casu, B., Molyneux, P., 2003. A Comparative Study of Efficiency in European Banking. Applied Economics 35, 1865--1876.

Cavallo, L., Rossi, S., 2001. Scale and Scope Economies in the European Banking Systems. Journal of Multinational Financial Management 11, 4-5, 515--531.

Cornwell, C., Schmidt, P., Sickles, R., 1990. Production Frontiers with Cross-Sectional and Time-Series Variation in Efficiency Levels. Journal of Econometrics 46, 185--200.

De Bandt, O., Davis, P., 2000. Competition, Contestability and Market Structure in European Banking Sectors on the Eve of EMU. Journal of Banking and Finance 24, 6, 1045--1066.

Dermine, J., 2003. Banking in Europe: Past, Present and Future, in: Gaspar, V., Hartmann, P., Sleijpen, O. (Eds), The Transformation of the European Financial System, European Central Bank.

Esho, N., 2001. The Determinants of Cost Efficiency in Cooperative Financial Institutions: Australian Evidence. Journal of Banking and Finance 25, 5, 941--964.

European Central Bank, 2007. EU Banking Structures, October.

European Commission, 2002. Study on the Quantification of the Macro-Economic Impact of Integration, Corporate Finance and Economic Growth, London Economic, November.

European Economy, 1988. Creation of a European Financial Area. Commission of the European Communities 36, EU, Brussels.

Fernandez de Guevara, J., Maudos, J., Perez, F., 2005. Market Power in European Banking Sectors. Journal of Financial Services Research 27, 2, 109--137.

Fernandez de Guevara, J., Maudos, J., Perez, F., 2007. Integration and Competition in the European Financial Markets. Journal of International Money and Finance 26, 1, 26--45.

Fung, M., 2006. Scale Economies, X-Efficiency, and Convergence of Productivity among Bank Holding Companies. Journal of Banking and Finance 30, 2857--2874.

Goddard, J., Molyneux, P., Wilson, J., 2004. The Profitability of European Banks: A Cross-Sectional and Dynamic Panel Analysis. The Manchester School 72, 3, 363--381.

Greene, W.H., 1990. A Gamma-Distributed Stochastic Frontier Model. Journal of Econometrics 46, 141--163.

Guiso, L., Japelli, T., Padula, M., Pagano, M., 2004. Financial Market Integration and Economic Growth in the EU. Economic Policy 525--577.

Hasan, I., Marton, K., 2003. Development and Efficiency of the Banking Sector in a Transitional Economy. Journal of Banking and Finance 27, 12, 2249--2271.

Jondrow, J., Lovell, C.A.K., Materov, I., Schmidt, P., 1982. On the Estimation of Technical Inefficiency in the Stochastic Frontier Production Function Model. Journal of Econometrics 19, 233--238.

Kumbhakar, S., Lovell, C.A.K., 2000. Stochastic Frontier Analysis, Cambridge University Press.

Lozano-Vivas, A., Pastor, J.T., Hasan, I., 2001. European Bank Performance beyond Country Borders: What Really Matters ? European Finance Review 5, 1-2, 141--165.

Lozano-Vivas, A., Pastor, J.T., Pastor, J.M., 2002. An Efficiency Comparison of European Banking Systems operating under Different Environmental Conditions. Journal of Productivity Analysis 18, 1, 59--77.

Maudos, J., Fernandez de Guevara, J., 2004. Factors explaining the interest margin in the banking sectors of the European Union. Journal of Banking and Finance 28, 9, 2259--2281.

Maudos, J., Fernandez de Guevara, J., 2007. The Cost of Market Power in Banking: Social Welfare Loss vs. Cost Inefficiency. Journal of Banking and Finance 31, 2103--2125.

Maudos, J., Pastor, J.M., Perez, F., Quesada, J., 2002. Cost and Profit Efficiency in European Banks. Journal of International Financial Markets, Institutions and Money 12, 1, 33--58.

McAllister, P., McManus, D., 1993. Resolving the Scale Efficiency Puzzle in Banking. Journal of Banking and Finance 17, 389--406.

Parikh, A., Shibata, M., 2004. Does Trade Liberalization accelerate Convergence in Per Capita Incomes in Developing Countries ? Journal of Asian Economics 15, 33--38. 
Quah, D., 1996. Empirics for Economic Growth and Convergence. European Economic Review 40, 1353-1376.

Rosse, J.N., Panzar, J.C, 1977. Chamberlin vs Robinson: An Empirical Study for Monopoly Rents. Bell Laboratories Economic Discussion Paper.

Schure, P., Wagenvoort, R., O’Brien, D., 2004. The Efficiency and the Conduct of European Banks: Developments after 1992. Review of Financial Economics 13, 371--396.

Vander Vennet, R., 2002. Cost and Profit Efficiency of Financial Conglomerates and Universal Banks in Europe. Journal of Money, Credit and Banking 34, 1, 254--282.

Weill, L., 2004. Measuring Cost Efficiency in European Banking: A Comparison of Frontier Techniques. Journal of Productivity Analysis 21, 133--152.

Yafeh, Y., Yosha, O., 2001. The Industrial Organization of Financial Systems and the Strategic Use of Relationship Banking. European Finance Review 5, 1-2, 63--78. 


\section{Table 1}

\section{Descriptive statistics of the variables 1994-2005}

The table displays the descriptive statistics for the variables used for the efficiency scores. Loans, investment assets, total assets, and total costs re in thousand euros. Input prices are in percentage. $\mathrm{N}=14447$ observations.

\begin{tabular}{lllll}
\hline & Mean & S.D. & Minimum & Maximum \\
\hline $\begin{array}{l}\text { Outputs } \\
\quad \text { Loans }\end{array}$ & $2,433,812.0$ & $9,113,975.7$ & $1,452.0$ & $254,472,312.0$ \\
$\quad \begin{array}{l}\text { Investment assets } \\
\text { Input prices }\end{array}$ & $2,393,087.8$ & $11,533,754.0$ & 233.0 & $304,719,202.0$ \\
$\quad$ Price of labor & & & & \\
$\quad \begin{array}{l}\text { Price of physical capital } \\
\quad \text { Price of borrowed funds }\end{array}$ & 1.35 & 0.48 & 0.01 & 3.18 \\
$\begin{array}{l}\text { Other characteristics } \\
\quad \text { Total assets }\end{array}$ & 7.81 & 1.22 & 0.24 & 9.00 \\
$\quad$ Total costs & 75.44 & 45.12 & 0.34 & 294.75 \\
\hline
\end{tabular}




\section{Table 2}

\section{Cost efficiency scores of banks}

This table displays the means of cost efficiency scores for each year and each country. Production approach is adopted for the specification of inputs and outputs. Efficiency scores are estimated with stochastic frontier approach. All scores are in percentage. Evolution is the difference between the average cost efficiency score in 2005 and the average cost efficiency score in $1994 . *, * *, * * *$ denote a difference significantly different from 0 at the $10 \%, 5 \%$ or $1 \%$ level.

\begin{tabular}{|c|c|c|c|c|c|c|c|c|c|c|c|c|c|}
\hline & 1994 & 1995 & 1996 & 1997 & 1998 & 1999 & 2000 & 2001 & 2002 & 2003 & 2004 & 2005 & Evolution \\
\hline Austria & 74.28 & 73.51 & 77.75 & 77.06 & 77.52 & 80.83 & 79.97 & 78.10 & 78.61 & 77.81 & 77.85 & 82.13 & $+7.85^{* * *}$ \\
\hline Belgium & 77.87 & 75.41 & 81.62 & 81.88 & 86.75 & 86.75 & 84.15 & 84.09 & 86.32 & 80.64 & 78.28 & 87.64 & $+9.77 * * *$ \\
\hline Denmark & 71.70 & 71.02 & 77.67 & 79.82 & 83.16 & 86.41 & 84.14 & 82.71 & 82.07 & 79.19 & 83.40 & 86.26 & $+14.57 * * *$ \\
\hline France & 78.90 & 77.49 & 80.31 & 81.68 & 84.71 & 87.31 & 86.66 & 83.77 & 82.65 & 80.22 & 81.73 & 85.48 & $+6.58 * * *$ \\
\hline Germany & 73.71 & 71.13 & 74.78 & 75.72 & 78.91 & 81.02 & 79.38 & 78.50 & 78.04 & 74.91 & 75.69 & 81.84 & $+8.13^{* * *}$ \\
\hline Italy & 70.93 & 68.85 & 73.13 & 77.08 & 81.43 & 86.52 & 84.73 & 83.99 & 84.40 & 82.01 & 81.91 & 85.82 & $+14.89 * * *$ \\
\hline Luxembourg & 72.33 & 71.01 & 76.40 & 77.73 & 77.93 & 86.37 & 84.72 & 84.26 & 84.41 & 84.37 & 82.58 & 90.88 & $+18.54 * * *$ \\
\hline Portugal & 61.03 & 61.69 & 68.61 & 68.74 & 72.52 & 79.34 & 74.90 & 74.33 & 76.32 & 74.52 & 78.14 & 88.34 & $+27.31^{* * *}$ \\
\hline Spain & 62.87 & 58.90 & 62.82 & 69.81 & 76.49 & 81.11 & 79.56 & 78.88 & 78.92 & 73.77 & 76.17 & 80.32 & $+17.45^{* * *}$ \\
\hline UK & 74.37 & 66.48 & 75.80 & 77.84 & 84.22 & 87.30 & 80.10 & 84.02 & 88.83 & 83.58 & 83.44 & 86.29 & +11.92 \\
\hline
\end{tabular}




\section{Table 3}

\section{Tests of convergence of efficiency scores}

The table displays the results of the tests of $\beta$ convergence and $\sigma$ convergence performed at the country level. In the test of $\beta$ convergence, the explained variable is $\ln E F F_{i, t}-\ln E F F_{i, t-1}$, with $E F F_{i, t}$ and $E F F_{i, t-1}$ the mean efficiency scores of country i respectively in year $\mathrm{t}$ and year $\mathrm{t}-1$. In the test of $\sigma$ convergence, the explained variable is $\Delta W_{i, t}$, in which $\Delta W_{i, t}=W_{i, t}-W_{i, t-1}, W_{i, t}=\ln E F F_{i, t}-M E F F_{t}, \ln E F F_{i, t}$ the logarithm of the efficiency score of country $\mathrm{i}$ in year $\mathrm{t}$, and $M E F F_{t}$ the mean of $\ln E F F_{i, t}$ for each period. *, **, *** denote an estimate significantly different from 0 at the $10 \%, 5 \%$ or $1 \%$ level. Country dummy variables are not reported. $\mathrm{N}=110$.

\section{Coefficient t-value}

$\beta$ convergence

\begin{tabular}{lcc} 
Intercept & $1.18^{* * *}$ & $(4.20)$ \\
$\ln \left(E F F_{t-1}\right)$ & $-0.26^{* * *}$ & $(4.13)$ \\
Adjusted $\mathrm{R}^{2}$ & 0.0858 & \\
\hline \multicolumn{2}{c}{ convergence } & \\
\hline Intercept & $8.55^{\mathrm{E}-3}$ & \\
$W_{i, t-1}$ & $-0.34^{* * *}$ & $(1.01)$ \\
Adjusted $\mathrm{R}^{2}$ & 0.2132 & \\
\hline
\end{tabular}




\section{Table 4}

\section{Cost efficiency scores of banks (WITHIN model)}

This table displays the means of cost efficiency scores for each year and each country. Intermediation approach is adopted for the specification of inputs and outputs. All scores are in percentage. Evolution is the difference between the average cost efficiency score in 2005 and the average cost efficiency score in 1994 . *, **, *** denote a difference significantly different from 0 at the $10 \%, 5 \%$ or $1 \%$ level.

\begin{tabular}{lcccccccccccccc}
\hline & 1994 & 1995 & 1996 & 1997 & 1998 & 1999 & 2000 & 2001 & 2002 & 2003 & 2004 & 2005 & Evolution \\
\hline Austria & 53.36 & 53.08 & 53.99 & 53.62 & 62.84 & 77.04 & 79.47 & 55.72 & 64.74 & 53.05 & 61.20 & 73.97 & $+20.60^{* * *}$ \\
Belgium & 49.55 & 50.89 & 50.78 & 50.19 & 58.83 & 72.66 & 74.83 & 53.66 & 64.35 & 51.07 & 57.90 & 68.59 & $+19.05^{* * *}$ \\
Denmark & 51.58 & 51.09 & 50.91 & 50.15 & 59.79 & 73.13 & 76.13 & 55.54 & 62.42 & 48.79 & 56.81 & 68.86 & $+17.27 * * *$ \\
France & 48.90 & 48.85 & 48.77 & 47.91 & 56.56 & 69.51 & 71.90 & 51.61 & 60.44 & 49.02 & 56.55 & 68.67 & $+19.77 * * *$ \\
Germany & 50.61 & 50.70 & 50.92 & 49.90 & 58.86 & 71.88 & 73.87 & 52.53 & 60.99 & 49.25 & 57.11 & 69.13 & $+18.52 * * *$ \\
Italy & 47.98 & 50.18 & 52.37 & 52.61 & 62.49 & 76.60 & 79.70 & 59.02 & 69.68 & 55.87 & 62.42 & 77.28 & $+29.30 * * *$ \\
Luxembourg & 48.59 & 48.42 & 48.11 & 47.44 & 55.89 & 69.21 & 71.80 & 52.75 & 61.70 & 50.29 & 57.48 & 70.00 & $+21.41^{* * *}$ \\
Portugal & 49.92 & 50.27 & 50.26 & 47.07 & 54.33 & 67.57 & 68.65 & 49.95 & 56.51 & 45.75 & 49.17 & 63.60 & $+13.69 *$ \\
Spain & 47.97 & 48.52 & 48.57 & 47.72 & 56.19 & 68.80 & 70.92 & 50.01 & 60.08 & 46.92 & 54.11 & 66.91 & $+18.94 * * *$ \\
UK & 55.06 & 53.19 & 55.34 & 53.44 & 68.20 & 74.07 & 68.42 & 56.95 & 63.14 & 56.88 & 64.63 & 76.14 & $+21.08 * * *$ \\
\hline
\end{tabular}




\section{Table 5}

\section{Tests of convergence of efficiency scores (WITHIN model)}

The table displays the results of the tests of $\beta$ convergence and $\sigma$ convergence performed at the country level. In the test of $\beta$ convergence, the explained variable is $\ln E F F_{i, t}-\ln E F F_{i, t-1}$, with $E F F_{i, t}$ and $E F F_{i, t-1}$ the mean efficiency scores of country i respectively in year $\mathrm{t}$ and year $\mathrm{t}-1$. In the test of $\sigma$ convergence, the explained variable is $\Delta W_{i, t}$, in which $\Delta W_{i, t}=W_{i, t}-W_{i, t-1}, W_{i, t}=\ln E F F_{i, t}-M E F F_{t}, \ln E F F_{i, t}$ the logarithm of the efficiency score of country $\mathrm{i}$ in year $\mathrm{t}$, and $M E F F_{t}$ the mean of $\ln E F F_{i, t}$ for each period. *, **, *** denote an estimate significantly different from 0 at the $10 \%, 5 \%$ or $1 \%$ level. Country dummy variables are not reported. $\mathrm{N}=110$.

\section{Coefficient t-value}

$\beta$ convergence

\begin{tabular}{lcc} 
Intercept & $2.52^{* * *}$ & $(6.40)$ \\
$\ln \left(E F F_{t-1}\right)$ & $-0.62^{* * *}$ & $(6.36)$ \\
Adjusted $\mathrm{R}^{2}$ & 0.2191 & \\
\hline$\sigma$ convergence & & \\
\hline Intercept & $-0.02^{* *}$ & $(2.11)$ \\
$W_{i, t-1}$ & $-0.75^{* * *}$ & $(7.44)$ \\
Adjusted $\mathrm{R}^{2}$ & 0.3094 & \\
\hline
\end{tabular}




\section{Table 6}

\section{Cost efficiency scores of banks: Production Approach}

This table displays the means of cost efficiency scores for each year and each country. Efficiency scores are estimated with stochastic frontier approach. All scores are in percentage. Evolution is the difference between the average cost efficiency score in 2005 and the average cost efficiency score in 1994 . *, **, *** denote a difference significantly different from 0 at the $10 \%, 5 \%$ or $1 \%$ level.

\begin{tabular}{|c|c|c|c|c|c|c|c|c|c|c|c|c|c|}
\hline & 1994 & 1995 & 1996 & 1997 & 1998 & 1999 & 2000 & 2001 & 2002 & 2003 & 2004 & 2005 & Evolution \\
\hline Austria & 65.89 & 65.70 & 69.16 & 68.24 & 67.81 & 68.91 & 69.86 & 69.21 & 69.29 & 68.46 & 65.87 & 70.11 & +4.22 \\
\hline Belgium & 71.04 & 69.22 & 74.29 & 75.24 & 79.97 & 77.40 & 76.42 & 77.65 & 79.97 & 73.62 & 68.37 & 77.11 & $+6.08^{*}$ \\
\hline Denmark & 65.32 & 65.40 & 73.08 & 75.74 & 77.41 & 79.42 & 78.26 & 78.06 & 78.08 & 76.15 & 77.83 & 82.72 & $+17.39 * * *$ \\
\hline France & 74.94 & 74.04 & 75.55 & 77.13 & 80.10 & 80.31 & 82.23 & 79.93 & 77.76 & 75.83 & 75.56 & 80.01 & $+5.07 * * *$ \\
\hline Germany & 67.38 & 65.49 & 68.19 & 69.22 & 71.39 & 70.81 & 71.61 & 72.18 & 71.04 & 67.19 & 64.99 & 72.07 & $+4.70 * * *$ \\
\hline Italy & 62.67 & 61.10 & 62.36 & 66.41 & 70.66 & 76.16 & 75.69 & 75.66 & 76.31 & 73.27 & 71.44 & 76.51 & $+13.84 * * *$ \\
\hline Luxembourg & 64.26 & 62.28 & 64.68 & 67.23 & 65.92 & 72.63 & 74.73 & 75.20 & 76.02 & 76.25 & 75.48 & 80.09 & $+15.83 * * *$ \\
\hline Portugal & 52.05 & 53.95 & 59.75 & 59.55 & 64.92 & 67.30 & 66.41 & 68.44 & 69.48 & 68.77 & 72.90 & 82.15 & $+30.10 * * *$ \\
\hline Spain & 55.83 & 52.64 & 55.15 & 63.09 & 70.15 & 72.87 & 73.33 & 74.16 & 74.18 & 70.81 & 70.02 & 74.39 & $+18.55^{* * *}$ \\
\hline UK & 68.21 & 59.50 & 69.14 & 72.26 & 79.41 & 80.46 & 73.17 & 77.01 & 84.70 & 80.12 & 77.23 & 73.21 & +5.01 \\
\hline
\end{tabular}




\section{Table 7}

\section{Tests of convergence of efficiency scores (production approach)}

The table displays the results of the tests of $\beta$ convergence and $\sigma$ convergence performed at the country level. In the test of $\beta$ convergence, the explained variable is $\ln E F F_{i, t}-\ln E F F_{i, t-1}$, with $E F F_{i, t}$ and $E F F_{i, t-1}$ the mean efficiency scores of country i respectively in year $\mathrm{t}$ and year $\mathrm{t}-1$. In the test of $\sigma$ convergence, the explained variable is $\Delta W_{i, t}$, in which $\Delta W_{i, t}=W_{i, t}-W_{i, t-1}, W_{i, t}=\ln E F F_{i, t}-M E F F_{t}, \ln E F F_{i, t}$ the logarithm of the efficiency score of country $\mathrm{i}$ in year $\mathrm{t}$, and $M E F F_{t}$ the mean of $\ln E F F_{i, t}$ for each period. *, **, *** denote an estimate significantly different from 0 at the $10 \%, 5 \%$ or $1 \%$ level. Country dummy variables are not reported. $\mathrm{N}=110$.

\section{Coefficient t-value}

\section{$\beta$ convergence}

$\begin{array}{ll}\text { Intercept } & 1.01^{* * *} \\ \ln \left(E F F_{t-1}\right) & -0.23^{* * *}\end{array}$

Adjusted R ${ }^{2}$

0.0967

\section{$\sigma$ convergence}

\begin{tabular}{lcc}
\hline Intercept & $-2.29^{\mathrm{E}-3}$ & $(0.19)$ \\
$W_{i, t-1}$ & $-0.34^{* * *}$ & $(4.11)$ \\
Adjusted $\mathrm{R}^{2}$ & 0.1260 & \\
\hline
\end{tabular}




\section{Table 8}

\section{H-statistic in the EU 1994-2005}

This table displays the H-statistic provided by the Rosse-Panzar model for each year and each country. It is the sum of elasticities of total revenues to the input prices. of cost efficiency scores for each year and each country. Evolution is the difference between the H-statistic in 2005 and the H-statistic in 1994. *, **, *** denote a difference significantly different from 0 at the $10 \%, 5 \%$ or $1 \%$ level.

\begin{tabular}{|c|c|c|c|c|c|c|c|c|c|c|c|c|c|}
\hline & 1994 & 1995 & 1996 & 1997 & 1998 & 1999 & 2000 & 2001 & 2002 & 2003 & 2004 & 2005 & Evolution \\
\hline Austria & 0.7076 & 0.6560 & 0.5922 & 0.5946 & 0.5782 & 0.6232 & 0.5917 & 0.6177 & 0.5800 & 0.5811 & 0.6820 & 0.6285 & -0.0791 \\
\hline Belgium & 0.6914 & 0.6194 & 0.6287 & 0.6119 & 0.6074 & 0.6346 & 0.6502 & 0.5197 & 0.4560 & 0.5849 & 0.6818 & 0.6218 & -0.0696 \\
\hline Denmark & 0.7038 & 0.6063 & 0.5502 & 0.3945 & 0.4260 & 0.5301 & 0.4275 & 0.5390 & 0.4835 & 0.6069 & 0.5290 & 0.5013 & -0.2025 \\
\hline France & 0.6915 & 0.6855 & 0.6426 & 0.6270 & 0.5757 & 0.5907 & 0.5474 & 0.5975 & 0.5592 & 0.5955 & 0.6409 & 0.5805 & -0.1110 \\
\hline Germany & 0.6799 & 0.6208 & 0.5774 & 0.5444 & 0.5375 & 0.5690 & 0.5471 & 0.5899 & 0.5572 & 0.5631 & 0.6250 & 0.5724 & -0.1075 \\
\hline Italy & 0.6928 & 0.6013 & 0.5599 & 5704 & 0.5980 & 0.6516 & 0.6048 & 0.5827 & 0.5335 & 0.5751 & 0.6657 & 0.6036 & -0.0892 \\
\hline Luxembourg & 0.8055 & 0.7256 & 0.6865 & 0.6006 & 0.6161 & 0.6644 & 0.6233 & 0.6942 & 0.6010 & 0.5544 & 0.6072 & 0.3769 & -0.4286 \\
\hline Portugal & 0.7001 & 0.6437 & 0.5631 & 0.4860 & 0.5237 & 0.5820 & 0.6226 & 0.6703 & 0.6795 & 0.5993 & 0.6032 & 0.5995 & -0.1006 \\
\hline Spain & 0.6565 & 0.5994 & 0.5724 & 0.5123 & 0.5042 & 0.5155 & 0.5543 & 0.6080 & 0.4436 & 0.5638 & 0.6387 & 0.6094 & -0.0471 \\
\hline UK & 0.6866 & 0.6724 & 0.6357 & 0.6189 & 0.3435 & 0.4366 & 0.5089 & 0.4977 & 0.5329 & 0.5119 & 0.6606 & 0.6534 & -0.0332 \\
\hline
\end{tabular}




\section{Table 9}

\section{Tests of convergence of the $\mathbf{H}$-statistic}

The table displays the results of the tests of $\beta$ convergence and $\sigma$ convergence performed at the country level. In the test of $\beta$ convergence, the explained variable is $\ln H_{i, t}-\ln H_{i, t-1}$, with $H_{i, t}$ and $H_{i, t-1}$ the H-statistic of country i respectively in year t and year t-1. In the test of $\sigma$ convergence, the explained variable is $\Delta W_{i, t}$, in which $\Delta W_{i, t}=W_{i, t}-W_{i, t-1}, W_{i, t}=\ln H_{i, t}-M H_{t}$, $\ln H_{i, t}$ the logarithm of the H-statistic of country i in year t, and $M H_{t}$ the mean of $\ln H_{i, t}$ for each period. *, **, *** denote an estimate significantly different from 0 at the $10 \%$, $5 \%$ or $1 \%$ level. Country dummy variables are not reported. $\mathrm{N}=110$.

\begin{tabular}{lcc} 
& Coefficient & t-value \\
\hline Inconvergence & & \\
Intercept & $-0.35^{* * *}$ & $(6.68)$ \\
ln $\left(E F F_{t-1}\right)$ & $-0.64^{* * *}$ & $(7.03)$ \\
Adjusted $\mathrm{R}^{2}$ & 0.2795 & \\
\hline$\sigma$ convergence & & \\
\hline Intercept & $0.06^{* *}$ & $(2.09)$ \\
$W_{i, t-1}$ & $-0.73^{* * *}$ & $(7.44)$ \\
Adjusted $\mathrm{R}^{2}$ & 0.2964 & \\
\hline
\end{tabular}




\section{PAPIERS}

\section{Laboratoire de Recherche en Gestion \& Economie (LARGE)}

D.R. $\mathrm{n}^{\circ} 1$ "Bertrand Oligopoly with decreasing returns to scale", J. Thépot, décembre 1993

D.R. $\mathrm{n}^{\circ} 2$ "Sur quelques méthodes d'estimation directe de la structure par terme des taux d'intérêt", P. Roger - N. Rossiensky, janvier 1994

D.R. $n^{\circ} 3$ "Towards a Monopoly Theory in a Managerial Perspective", J. Thépot, mai 1993

D.R. n 4 "Bounded Rationality in Microeconomics", J. Thépot, mai 1993

D.R. n 5 "Apprentissage Théorique et Expérience Professionnelle", J. Thépot, décembre 1993

D.R. $n^{\circ} 6$ "Stratégic Consumers in a Duable-Goods Monopoly", J. Thépot, avril 1994

D.R. n 7 "Vendre ou louer ; un apport de la théorie des jeux", J. Thépot, avril 1994

D.R. $n^{\circ} 8$ "Default Risk Insurance and Incomplete Markets", Ph. Artzner - FF. Delbaen, juin 1994

D.R. $n^{\circ} 9$ "Les actions à réinvestissement optionnel du dividende", C. Marie-Jeanne - P. Roger, janvier 1995

D.R. $n^{\circ} 10$ "Forme optimale des contrats d'assurance en présence de coûts administratifs pour l'assureur", S. Spaeter, février 1995

D.R. n 11 "Une procédure de codage numérique des articles", J. Jeunet, février 1995

D.R. $n^{\circ} 12$ Stabilité d'un diagnostic concurrentiel fondé sur une approche markovienne du comportement de rachat du consommateur", N. Schall, octobre 1995

D.R. $n^{\circ} 13$ "A direct proof of the coase conjecture", J. Thépot, octobre 1995

D.R. n 14 "Invitation à la stratégie", J. Thépot, décembre 1995

D.R. n 15 "Charity and economic efficiency", J. Thépot, mai 1996 
D.R. $n^{\circ} 16$ "Princing anomalies in financial markets and non linear pricing rules", P. Roger, mars 1996

D.R. n 17 "Non linéarité des coûts de l'assureur, comportement de prudence de l'assuré et contrats optimaux", S. Spaeter, avril 1996

D.R. $n^{\circ} 18$ "La valeur ajoutée d'un partage de risque et l'optimum de Pareto : une note", L. Eeckhoudt - P. Roger, juin 1996

D.R. $\mathrm{n}^{\circ} 19$ "Evaluation of Lot-Sizing Techniques : A robustess and Cost Effectiveness Analysis", J. Jeunet, mars 1996

D.R. n 20 "Entry accommodation with idle capacity", J. Thépot, septembre 1996

D.R. n 21 "Différences culturelles et satisfaction des vendeurs : Une comparaison internationale", E. Vauquois-Mathevet - J.Cl. Usunier, novembre 1996

D.R. $\mathrm{n}^{\circ} 22$ "Evaluation des obligations convertibles et options d'échange", A. Schmitt - F. Home, décembre 1996

D.R n 23 "Réduction d'un programme d'optimisation globale des coûts et diminution du temps de calcul, J. Jeunet, décembre 1996

D.R. $n^{\circ} 24$ "Incertitude, vérifiabilité et observabilité : Une relecture de la théorie de l'agence", J. Thépot, janvier 1997

D.R. $\mathrm{n}^{\circ} 25$ "Financement par augmentation de capital avec asymétrie d'information : l'apport du paiement du dividende en actions", C. Marie-Jeanne, février 1997

D.R. $\mathrm{n}^{\circ} 26$ "Paiement du dividende en actions et théorie du signal", C. Marie-Jeanne, février 1997

D.R. n 27 "Risk aversion and the bid-ask spread", L. Eeckhoudt - P. Roger, avril 1997

D.R. $n^{\circ} 28$ "De l'utilité de la contrainte d'assurance dans les modèles à un risque et à deux risques", S. Spaeter, septembre 1997

D.R. $n^{\circ} 29$ "Robustness and cost-effectiveness of lot-sizing techniques under revised demand forecasts", J. Jeunet, juillet 1997

D.R. $n^{\circ} 30$ "Efficience du marché et comparaison de produits à l'aide des méthodes d'enveloppe (Data envelopment analysis)", S. Chabi, septembre 1997

D.R. n 31 "Qualités de la main-d'œuvre et subventions à l'emploi : Approche microéconomique", J. Calaza - P. Roger, février 1998

D.R n 32 "Probabilité de défaut et spread de taux : Etude empirique du marché français", M. Merli - P. Roger, février 1998

D.R. n 33 "Confiance et Performance : La thèse de Fukuyama", 


\section{J.Cl. Usunier - P. Roger, avril 1998}

D.R. $n^{\circ} 34$ "Measuring the performance of lot-sizing techniques in uncertain environments", J. Jeunet - N. Jonard, janvier 1998

D.R. n 35 "Mobilité et décison de consommation : premiers résultas dans un cadre monopolistique", Ph. Lapp, octobre 1998

D.R. $\mathrm{n}^{\circ} 36$ "Impact du paiement du dividende en actions sur le transfert de richesse et la dilution du bénéfice par action", C. Marie-Jeanne, octobre 1998

D.R. n ${ }^{\circ} 37$ "Maximum resale-price-maintenance as Nash condition", J. Thépot, novembre 1998

D.R. $\mathrm{n}^{\circ} 38$ "Properties of bid and ask prices in the rank dependent expected utility model", P. Roger, décembre 1998

D.R. n 39 "Sur la structure par termes des spreads de défaut des obligations », Maxime Merli / Patrick Roger, septembre 1998

D.R. $n^{\circ} 40 \quad$ "Le risque de défaut des obligations : un modèle de défaut temporaire de l'émetteur", Maxime Merli, octobre 1998

D.R. n ${ }^{\circ} 41$ "The Economics of Doping in Sports", Nicolas Eber / Jacques Thépot, février 1999

D.R. $\mathrm{n}^{\circ} 42$ "Solving large unconstrained multilevel lot-sizing problems using a hybrid genetic algorithm", Jully Jeunet, mars 1999

D.R n 43 "Niveau général des taux et spreads de rendement", Maxime Merli, mars 1999

D.R. $\mathrm{n}^{\circ} 44$ "Doping in Sport and Competition Design", Nicolas Eber / Jacques Thépot, septembre 1999

D.R. n 45 "Interactions dans les canaux de distribution", Jacques Thépot, novembre 1999

D.R. n 46 "What sort of balanced scorecard for hospital", Thierry Nobre, novembre 1999

D.R. n 47 "Le contrôle de gestion dans les PME", Thierry Nobre, mars 2000

D.R. n ${ }^{\circ} 48$ "Stock timing using genetic algorithms", Jerzy Korczak - Patrick Roger, avril 2000

D.R. n 49 "On the long run risk in stocks : A west-side story", Patrick Roger, mai 2000

D.R. $\mathrm{n}^{\circ} 50$ "Estimation des coûts de transaction sur un marché gouverné par les ordres : Le cas des composantes du CAC40", Laurent Deville, avril 2001

D.R. $n^{\circ} 51$ "Sur une mesure d'efficience relative dans la théorie du portefeuille de Markowitz", Patrick Roger / Maxime Merli, septembre 2001 
D.R. $n^{\circ} 52$ "Impact de l'introduction du tracker Master Share CAC 40 sur la relation de parité callput", Laurent Deville, mars 2002

D.R. n 53 "Market-making, inventories and martingale pricing", Patrick Roger / Christian At / Laurent Flochel, mai 2002

D.R. $n^{\circ} 54$ "Tarification au coût complet en concurrence imparfaite", Jean-Luc Netzer / Jacques Thépot, juillet 2002

D.R. $n^{\circ} 55$ "Is time-diversification efficient for a loss averse investor ?", Patrick Roger, janvier 2003

D.R. $\mathrm{n}^{\circ} 56$ “Dégradations de notations du leader et effets de contagion”, Maxime Merli / Alain Schatt, avril 2003

D.R. n 57 “Subjective evaluation, ambiguity and relational contracts”, Brigitte Godbillon, juillet 2003

D.R. $n^{\circ} 58$ "A View of the European Union as an Evolving Country Portfolio", Pierre-Guillaume Méon / Laurent Weill, juillet 2003

D.R. n 59 “Can Mergers in Europe Help Banks Hedge Against Macroeconomic Risk ?”, Pierre-Guillaume Méon / Laurent Weill, septembre 2003

D.R. $n^{\circ} 60$ "Monetary policy in the presence of asymmetric wage indexation", Giuseppe Diana / Pierre-Guillaume Méon, juillet 2003

D.R. $n^{\circ} 61$ “Concurrence bancaire et taille des conventions de services”, Corentine Le Roy, novembre 2003

D.R. n 62 “Le petit monde du CAC 40”, Sylvie Chabi / Jérôme Maati

D.R. $n^{\circ} 63$ "Are Athletes Different? An Experimental Study Based on the Ultimatum Game”, Nicolas Eber / Marc Willinger

D.R. n 64 "Le rôle de l'environnement réglementaire, légal et institutionnel dans la défaillance des banques : Le cas des pays émergents”, Christophe Godlewski, janvier 2004

D.R. $n^{\circ} 65$ "Etude de la cohérence des ratings de banques avec la probabilité de défaillance bancaire dans les pays émergents”, Christophe Godlewski, Mars 2004

D.R. n 66 "Le comportement des étudiants sur le marché du téléphone mobile : Inertie, captivité ou fidélité ?”, Corentine Le Roy, Mai 2004

D.R. $n^{\circ} 67$ "Insurance and Financial Hedging of Oil Pollution Risks”, André Schmitt / Sandrine Spaeter, September, 2004

D.R. $\mathrm{n}^{\circ} 68$ "On the Backwardness in Macroeconomic Performance of European Socialist Economies”, Laurent Weill, September, 2004

D.R. $n^{\circ} 69$ "Majority voting with stochastic preferences: The whims of a committee are smaller than the whims of its members”, Pierre-Guillaume Méon, September, 2004 
D.R. $\mathrm{n}^{\circ} 70$ "Modélisation de la prévision de défaillance de la banque : Une application aux banques des pays émergents”, Christophe J. Godlewski, octobre 2004

D.R. $\mathrm{n}^{\circ} 71$ "Can bankruptcy law discriminate between heterogeneous firms when information is incomplete ? The case of legal sanctions", Régis Blazy, october 2004

D.R. n 72 “La performance économique et financière des jeunes entreprises”, Régis Blazy/Bertrand Chopard, octobre 2004

D.R. $\mathrm{n}^{\circ} 73$ "Ex Post Efficiency of bankruptcy procedures : A general normative framework”, Régis Blazy / Bertrand Chopard, novembre 2004

D.R. n 74 “Full cost pricing and organizational structure”, Jacques Thépot, décembre 2004

D.R. $\mathrm{n}^{\circ} 75$ "Prices as strategic substitutes in the Hotelling duopoly”, Jacques Thépot, décembre 2004

D.R. n 76 "Réflexions sur l'extension récente de la statistique de prix et de production à la santé et à l'enseignement”, Damien Broussolle, mars 2005

D. R. n 77 "Gestion du risque de crédit dans la banque : Information hard, information soft et manipulation ”, Brigitte Godbillon-Camus / Christophe J. Godlewski

D.R. n 78 "Which Optimal Design For LLDAs”, Marie Pfiffelmann

D.R. $\mathrm{n}^{\circ} 79$ “Jensen and Meckling 30 years after : A game theoretic view”, Jacques Thépot

D.R. n 80 “Organisation artistique et dépendance à l'égard des ressources”, Odile Paulus, novembre 2006

D.R. $n^{\circ} 81$ "Does collateral help mitigate adverse selection? A cross-country analysis”, Laurent Weill -Christophe J. Godlewski, novembre 2006

D.R. $\mathrm{n}^{\circ} 82$ "Why do banks ask for collateral and which ones ?”, Régis Blazy - Laurent Weill, décembre 2006

D.R. $n^{\circ} 83$ "The peace of work agreement : The emergence and enforcement of a swiss labour market institution”, D. Broussolle, janvier 2006.

D.R. $\mathrm{n}^{\circ} 84$ "The new approach to international trade in services in view of services specificities : Economic and regulation issues”, D. Broussolle, septembre 2006.

D.R. $n^{\circ} 85$ "Does the consciousness of the disposition effect increase the equity premium" ?, P. Roger, juin 2007

D.R. n 86 "Les déterminants de la décision de syndication bancaire en France”, Ch. J. Godlewski

D.R. n 87 “Syndicated loans in emerging markets”, Ch. J. Godlewski / L. Weill, mars 2007

D.R. $n^{\circ} 88$ "Hawks and loves in segmented markets : A formal approach to competitive 
aggressiveness”, Claude d’Aspremont / R. Dos Santos Ferreira / J. Thépot, mai 2007

D.R. n 89 “On the optimality of the full cost pricing”, J. Thépot, février 2007

D.R. n'90 "SME's main bank choice and organizational structure : Evidence from France”, H. El Hajj Chehade / L. Vigneron, octobre 2007

D.R n 91 “How to solve St Petersburg Paradox in Rank-Dependent Models” ?, M. Pfiffelmann, octobre 2007

D.R. $\mathrm{n}^{\circ} 92$ "Full market opening in the postal services facing the social and territorial cohesion goal in France”, D. Broussolle, novembre 2007

D.R. $n^{\circ}$ 2008-01 A behavioural Approach to financial puzzles, M.H. Broihanne, M. Merli, P. Roger, janvier 2008

D.R. $\mathrm{n}^{\circ}$ 2008-02 What drives the arrangement timetable of bank loan syndication ?, Ch. J. Godlewski, février 2008

D.R. $n^{\circ}$ 2008-03 Financial intermediation and macroeconomic efficiency, Y. Kuhry, L. Weill, février 2008

D.R. $n^{\circ}$ 2008-04 The effects of concentration on competition and efficiency : Some evidence from the french audit market, G. Broye, L. Weill, février 2008

D.R. $\mathrm{n}^{\circ}$ 2008-05 Does financial intermediation matter for macroeconomic efficiency?, P.G. Méon, L. Weill, février 2008

D.R. $n^{\circ}$ 2008-06 Is corruption an efficient grease ?, P.G. Méon, L. Weill, février 2008

D.R. $\mathrm{n}^{\circ}$ 2008-07 Convergence in banking efficiency across european countries, L. Weill, Février 2008. 